\title{
原著
}

\section{内耳性めまいが疑われ当科を受診した脳血管障害症例の 急性期眼振所見}

\author{
小川 恭生・萩原 晃・清水 重敬・稲垣 太郎 \\ 大塚 康司・林麻美・鈴木 衞
}

A study of acute phase nystagmus in 15 patients with cerebrovascular lesions

Yasuo Ogawa, Akira Hagiwara, Shigetaka Shimizu, Taro Inagaki, Koji Otsuka, Mami Hayashi, Mamoru Suzuki Department of Otolaryngology, Tokyo Medical University

It is known that gaze-evoked nystagmus, upbeat nystagmus, down beat nystagmus and pure rotatory nystagmus are associated with central lesions, but these types of nystagmus do not always appear in the acute phase of vertigo in patients with a central disorder. In this study, we retrospectively investigated acute phase nystagmus in 15 patients with cerebrovascular lesions. All patients were attending an ENT clinic because of a lack of marked findings concerning neurological dysfunction except vertigo, but finally they were diagnosed as having vascular lesions in the posterior fossa, 3 patients with medulla infarction, 3 patients with pons infarction, 8 patients with cerebellar infarction and 1 patient with cerebellar hemorrhage.

At the initial visit to the ENT clinic, spontaneous nystagmus was observed in all patients with a brainstem infarction and in 3 out of 9 patients with cerebellar lesions. Their nystagmus was the horizontal type or the horizontal type with a torsional component. All patients initially were suspected of having peripheral lesions at the initial visit or on admission, but the direction and the type of nystagmus changed periodically and neurological symptoms except vertigo appeared subsequently to admission. Diagnosis of central lesion was made with MRI. It is difficult to differentiate central lesions from peripheral lesions on the grounds of the direction and type of nystagmus, but it is important to observe the changes in nystagmus and other neurological findings for the differential diagnosis of central lesions.

Key words: cerebellar infarction, brainstem infarction, vertigo, posterior inferior cerebellar artery, anterior inferior cerebellar artery, superior cerebellar artery 


\section{はじめに}

めまいの診察で最も重要なことは, 中枢性めま い,すなわち「危険なめまい」を鑑別することで ある。急性期のめまい患者の数\%に脳梗塞・脳出 血が含まれることが報告されている ${ }^{12)}$ 。中枢性め まいで当初から四肢麻痺, 意識障害, 第 8 脳神経 以外の脳神経症状などを伴う場合, はじめに内 科, 脳神経外科を受診することになるが, 中枢神 経症状がそしく回転性めまいを訴える場合や耳鳴 りなど螖牛症状の訴えがあった場合, 耳鼻咽喉科 で対応を迫られることになる。耳鼻咽喉科医にと って眼振所見は急性期めまい患者の中枢性・末梢 性鑑別のため重要な根拠となる。一般に中枢性を 示唆する眼振として注視方向性眼振, 上眼瞼向 き, 下眼瞼向きといった垂直性眼振が知られてい る。しかし著者らが行った以前の検討 ${ }^{1)}$ で, 当科 救急外来を受診した中枢性めまい患者の初診時に 上記のような眼振を認めた症例はなかった。今回 我々はめまいを主訴に当院を受診し, 当初内耳疾 患が疑われ後に原因が脳梗塞, 脳出血と判明した 症例の主に急性期眼振所見について, 代表症例を 呈示するとともに文献的考察を加え報告する。

\section{対 象}

2003年から2008年までにめまいを主訴に東京医 科大学耳鼻咽喉科を受診し, 当初内耳性めまいが 疑われたが後に CT, MRI 検査で脳幹梗塞, 小脳 梗塞・出血と診断した15例について検討した（表 1，2)。症例(2)，7)，(11，13に関しては過去の 報告 $^{13) 4(4)}$ で症例呈示している。

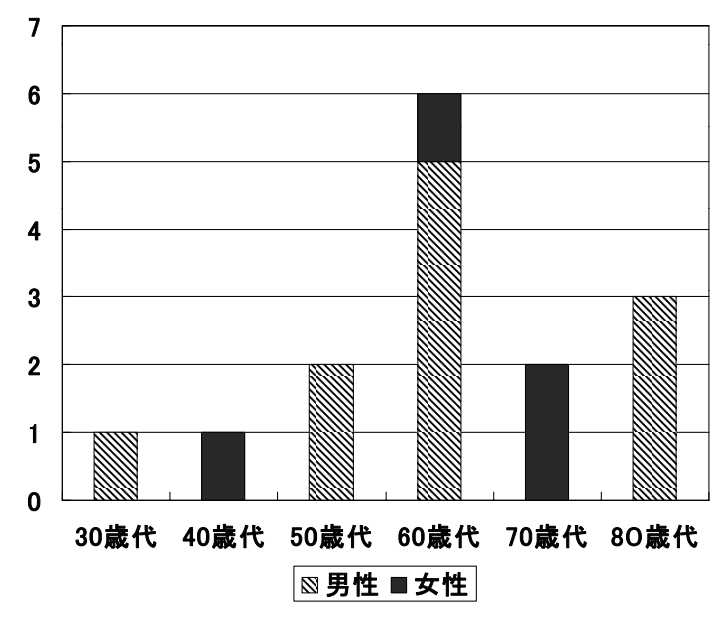

図 1 年齢分布と性別

表 $1 \mathrm{~A}$ 脳幹梗塞 6 例のまとめ

\begin{tabular}{|c|c|c|c|c|c|c|c|c|c|}
\hline & 年齢 & 性別 & $\begin{array}{c}\text { 受診まで } \\
\text { の日数 }\end{array}$ & $\begin{array}{c}\text { めまい } \\
\text { 性状 }\end{array}$ & 頭痛 & 受診形式 & 既往歴 & $\begin{array}{l}\text { 初診時 } \\
\text { 頭部 CT }\end{array}$ & 入院科 \\
\hline (1) & 58 & M & 同日 & 回転性 & - & $\begin{array}{c}\text { 救急 } \\
\text { 耳鼻咽喉科 }\end{array}$ & $\begin{array}{l}\text { 糖尿病 } \\
\text { 高血圧 } \\
\text { 高脂血症 }\end{array}$ & 正常 & 神経内科 \\
\hline (2) & 47 & M & 3 日 & 回転性 & + & $\begin{array}{l}\text { 他院 } \\
\text { 内科 }\end{array}$ & $\begin{array}{l}\text { 特記 } \\
\text { なし }\end{array}$ & 正常 & $\begin{array}{l}\text { 耳鼻咽喉科から } \\
\text { 神経内科へ } \\
\text { 転科 }\end{array}$ \\
\hline (3) & 62 & M & 1 日 & 浮動性 & + & $\begin{array}{c}\text { 消化器 } \\
\text { 内科 }\end{array}$ & 高脂血症 & 正常 & $\begin{array}{l}\text { 耳鼻咽喉科から } \\
\text { 経内科へ } \\
\text { 転科 }\end{array}$ \\
\hline (4) & 60 & M & 1 日 & 回転性 & - & $\begin{array}{l}\text { 救急 } \\
\text { 内科 }\end{array}$ & $\begin{array}{l}\text { 脳梗塞 } \\
\text { 糖尿病 }\end{array}$ & 正常 & $\begin{array}{l}\text { 耳鼻咽喉科から } \\
\text { 神経内科へ } \\
\text { 転科 }\end{array}$ \\
\hline (5) & 80 & $\mathrm{~F}$ & 同日 & 回転性 & - & $\begin{array}{c}\text { 救急 } \\
\text { 耳鼻咽喉科 }\end{array}$ & $\begin{array}{l}\text { 特記 } \\
\text { なし }\end{array}$ & 正常 & $\begin{array}{l}\text { 耳鼻咽喉科から } \\
\text { 神経内科へ } \\
\text { 転科 }\end{array}$ \\
\hline (6) & 72 & $\mathrm{~F}$ & 4 日 & 回転性 & - & 脳外科 & $\begin{array}{l}\text { 高血压 } \\
\text { 糖尿病 } \\
\text { 動脈瘤 }\end{array}$ & 正常 & $\begin{array}{l}\text { 耳鼻咽喉科から } \\
\text { 神経内科へ } \\
\text { 転科 }\end{array}$ \\
\hline
\end{tabular}


表 1 B 脳幹梗塞 6 例のまとめ

\begin{tabular}{|c|c|c|c|c|}
\hline & 初診時眼振所見 & 病巣 & $\begin{array}{c}\text { 中枢病変が } \\
\text { 疑われた理由 }\end{array}$ & 眼振所見の変化 \\
\hline (1) & & 左延髄梗塞 & $\begin{array}{c}5 \text { 日後 } \\
\text { 左上下肢失調 } \\
\text { 左顔面麻痺 } \\
\text { 構音障害 }\end{array}$ & $\begin{array}{c}\text { 外来経過観察にて } \\
\text { 眼振消失 }\end{array}$ \\
\hline (2) & & $\begin{array}{c}\text { 右延髄背外側梗塞 } \\
\text { 椎骨動脈解離 }\end{array}$ & $\begin{array}{c}3 \text { 日後 } \\
\text { 小脳症状 } \\
\text { 知覚障害 } \\
\text { 顔面知賞異常 }\end{array}$ & $\begin{array}{c}\text { 眼振方向が変化 } \\
\text { 頭位検査にて } \\
\text { 上眼瞼向き眼振 }\end{array}$ \\
\hline (3) & & 右延髄内側梗塞 & $\begin{array}{l}\text { 同日夜間 } \\
\text { 左片麻痺 } \\
\text { 構語障害 }\end{array}$ & 注視眼振 2 日後消失 \\
\hline (4) & ڤڤ & 左中小脳脚（橋） & $\begin{array}{c}3 \text { 日後 } \\
\text { 顔面知覚障害 } \\
\text { 顔面麻㽻 }\end{array}$ & 眼振 2 日後消失 \\
\hline (5) & & 橋梗塞（中央） & $\begin{array}{c}\text { 翌日 } \\
\text { 注視方向性眼振 }\end{array}$ & $\begin{array}{c}\text { 翌日注視方向性眼振瓿視眼振方向と頭位 } \\
\text { 眼振の方向に変化 }\end{array}$ \\
\hline (6) & 1 & 橋梗塞（中央） & $\begin{array}{l}\text { めまい感改善 } \\
\text { せず MRI 施行 }\end{array}$ & $\begin{array}{c}\text { 注視眼振認めるが } \\
\text { 頭位眼振認めず } \\
14 \text { 日後眼振消失 }\end{array}$ \\
\hline
\end{tabular}

\section{結 果}

性別・年齢：男性10例，女性 5 例であった。年 齢は35歳から83歳で, 平均年齢は65.3歳であった (図 1 )。

病巣部位: 延髄 3 例（表 $1 \mathrm{~A}, 1 \mathrm{~B}$ ), 橋 3 例 (表 $1 \mathrm{~A}, 1 \mathrm{~B}$ )，小脳が 9 例（表 $2 \mathrm{~A}, 2 \mathrm{~B}$ ）で あった。延髄梗塞は外側梗塞が 2 例, 内側梗塞が 1 例であった。橋梗塞では中小脳脚が 1 例, 中央 の梗塞が 2 例であった。小脳梗塞の部位の判定は Barth $ら^{5)}$ のシェーマを参考にした。小脳梗塞・ 出血の主な部位は一側の上小脳動脈（superior cerebellar artery; SCA）領域が 4 例，後下小脳 動脈領域（posterior inferior cerebellar artery; PICA）が 2 例, 前下小脳動脈（anterior inferior cerebellar artery；AICA）領域が 3 例であった。 多くは単一の動脈潅流域だけでなく他の動脈潅流 域にも病巣を伴っていた。

既往歴：高血圧 5 例, 糖尿病 5 例, 高脂血症 3
例, 脳梗塞 2 例, 脳動脈奇形 1 例, 動脈瘤 1 例, 卵巣囊腫 1 例, 特記すべき既往のない症例が 5 例 であった。

\section{めまいの性状}

脳幹梗塞では延髄外側梗塞の 2 例は回転性めま いを訴え, 内側梗塞の症例はふらつきの訴えであ った。橋梗塞 3 例とも回転性めまいの訴えであっ た。小脳出血の 1 例と小脳梗塞の 1 例でふらつき の訴えであったが，その他の症例の訴えは回転性 めまいであった。

症状出現から受診までの期間

当日が最も多く 7 例， 1 日が 4 例， 3 日 2 例， 4 日 1 例，6日 1 例であった。

当科受診までの経路

直接当科 (耳鼻咽喉科)を受診した症例が 7 例, 他院を含む内科もしくは総合診療科から内耳性め まいが疑われ，当科を受診した症例が 6 例，脳神 経外科から紹介されたのは 2 例であった。 
表 $2 \mathrm{~A}$ 小脳梗塞・出血 9 例のまとめ

\begin{tabular}{|c|c|c|c|c|c|c|c|c|c|}
\hline & 年齢 & 性別 & $\begin{array}{c}\text { 受診まで } \\
\text { の日数 }\end{array}$ & $\begin{array}{c}\text { めまい } \\
\text { 性状 }\end{array}$ & 頭痛 & 受診形式 & 既往歴 & $\begin{array}{l}\text { 初診時 } \\
\text { 頭部 CT }\end{array}$ & 入院 \\
\hline (7) & 80 & M & 同日 & 回転性 & - & $\begin{array}{c}\text { 救急 } \\
\text { 耳鼻咽喉科 }\end{array}$ & 不整脈 & 正常 & $\begin{array}{l}\text { 救急外来から } \\
\text { 鹵宅後堌 } \\
\text { 老年病科入院 }\end{array}$ \\
\hline (8) & 59 & M & 1 日 & 回転性 & - & $\begin{array}{l}\text { 救急 } \\
\text { 内科 }\end{array}$ & 胃潰瘍 & 正常 & $\begin{array}{l}\text { 耳鼻咽喉科から } \\
\text { 神経内科へ } \\
\text { 転科 }\end{array}$ \\
\hline (9) & 64 & M & 同日 & 回転性 & - & 総合診療科 & $\begin{array}{l}\text { 高血压 } \\
\text { 糖尿病 }\end{array}$ & 正常 & $\begin{array}{l}\text { 耳鼻咽喉科から } \\
\text { 神経内科へ } \\
\text { 転科 }\end{array}$ \\
\hline (10) & 67 & $\mathrm{~F}$ & 同日 & 浮動性 & + & $\begin{array}{c}\text { 救急 } \\
\text { 耳鼻咽喉科 }\end{array}$ & $\begin{array}{c}\text { 卵巣のう腫 } \\
\text { 肝炎 }\end{array}$ & 出血 & 脳外科 \\
\hline (11) & 35 & M & 同日 & 回転性 & + & $\begin{array}{l}\text { 他院 } \\
\text { 内科 }\end{array}$ & $\begin{array}{l}\text { 特記 } \\
\text { なし }\end{array}$ & 正常 & $\begin{array}{l}\text { 耳鼻咽喉科から } \\
\text { 神経内科へ } \\
\text { 転科 }\end{array}$ \\
\hline (12) & 65 & M & 同日 & 回転性 & - & $\begin{array}{c}\text { 救急 } \\
\text { 耳鼻咽喉科 }\end{array}$ & $\begin{array}{l}\text { 特記 } \\
\text { なし }\end{array}$ & 正常 & $\begin{array}{l}\text { 耳鼻咽喉科から } \\
\text { 脳外科へ転科 } \\
\text { 緊急手術 }\end{array}$ \\
\hline (13) & 68 & $\mathrm{~F}$ & 1 日 & 浮動性 & - & $\begin{array}{c}\text { 救急 } \\
\text { 耳鼻咽喉科 }\end{array}$ & $\begin{array}{l}\text { 高血压 } \\
\text { 糖尿病 } \\
\text { 脳梗塞 }\end{array}$ & 正常 & $\begin{array}{l}\text { 耳鼻咽喉科から } \\
\text { 神経内科へ } \\
\text { 転科 }\end{array}$ \\
\hline (14) & 79 & $\mathrm{~F}$ & 6 日 & 回転性 & + & $\begin{array}{c}\text { 他院 } \\
\text { 脳外科 }\end{array}$ & $\begin{array}{l}\text { 高血压 } \\
\text { 糖尿病 }\end{array}$ & 正常 & $\begin{array}{l}\text { 耳鼻咽喉科から } \\
\text { 老年病科へ } \\
\text { 転科 }\end{array}$ \\
\hline (15) & 83 & M & 3 日 & 回転性 & - & $\begin{array}{c}\text { 救急 } \\
\text { 耳鼻咽喉科 }\end{array}$ & $\begin{array}{l}\text { 特記 } \\
\text { なし }\end{array}$ & 正常 & $\begin{array}{l}\text { 耳鼻咽喉科から } \\
\text { 老年病科へ } \\
\text { 転科 }\end{array}$ \\
\hline
\end{tabular}

\section{初診時眼振所見}

脳幹梗塞例では, 当科初診時全例自発眼振がみ とめられた。注視眼振検査では, III $^{\circ}$ 眼振がみら れた症例が 5 例， I 眼振が 1 例であった。

小脳梗塞・出血例では, 初診時に自発眼振を認 めた症例は 9 例中 3 例であった。注視検査で III 眼振がみられた症例は 1 例あった。 I 眼振は 2 例あった。頭位眼振は注視眼振がみられた 4 例の ほかに 2 例, 計 6 例に認められた。いずれの眼振 も一方向性で, 注視方向性眼振や垂直性眼振とい った中枢性を示唆する眼振はみられなかった。

初診時頭部 CT

全例に初診時頭部 CTをおこなった。脳梗塞症 例では全例異常なかった。小脳出血例（症例(10)
では，救急外来で撮影し脳出血が判明した。小脳 出血性梗塞の 1 例（症例12) は初診時の CT では 異常なかったが, 翌日のCTで出血が確認され た。

\section{入院後の経過}

12例は内耳性めまいが疑われ，耳鼻咽喉科に入 院となった。症例(1)は, 耳鼻咽喉科救急外来, 一 般外来を 3 日通院後症状改善したが 5 日後症状が 増悪し, 神経内科入院となった。症例 (7)は耳鼻咽 喉科救急外来受診し, 点滴加療後帰宅したが翌朝 症状が増悪し当院老年病科に入院となった ${ }^{3)}$ 。症 例10は耳鼻咽喉科救急外来にて点滴後めまい症状 改善せず, 緊急 CT で出血が確認され脳神経外科 に入院となった。内耳性めまい疑いで耳鼻咽喉科 
表 2 B 小脳梗塞・出血 9 例のまとめ

$\mathrm{m}-\mathrm{SCA}$ ：上小脳動脈内側枝, 1-SCA：上小脳動脈外側枝

m-PICA : 後下小脳動脈内側枝, 1-PICA : 後下小脳動脈外側枝

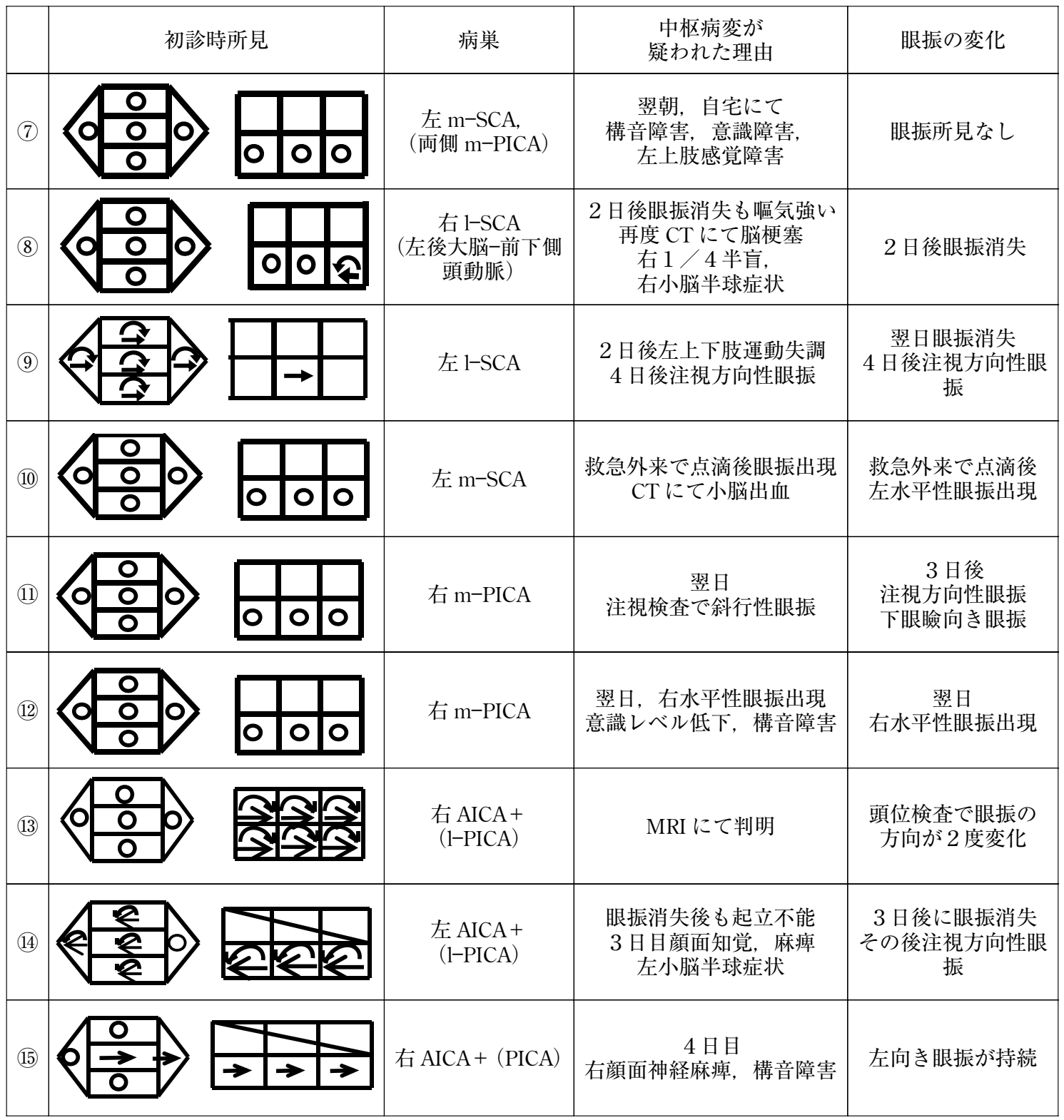

入院となった症例では，入院後にめまい，眼振以 外の神経学的所見, 中枢性を示唆する眼振所見が 出現し神経内科, 老年病科, 脳神経外科に転科と なった。

眼振所見の変化

多くの症例は初診時定方向性眼振がみられた
が, 眼振は翌日以降に変化した。脳幹梗塞例では, 初診時にみられた眼振は数日で消失した。症例(2) では定方向性眼振の方向に変化がみられ，症例(5) では翌日注視方向性眼振が出現し中枢性病変を疑 うきっかけとなった。また症例6 では注視眼振が 認められたが, 非注視下の頭位検査で眼振が減弱 


\section{症例 (1)眼振所見の変化}

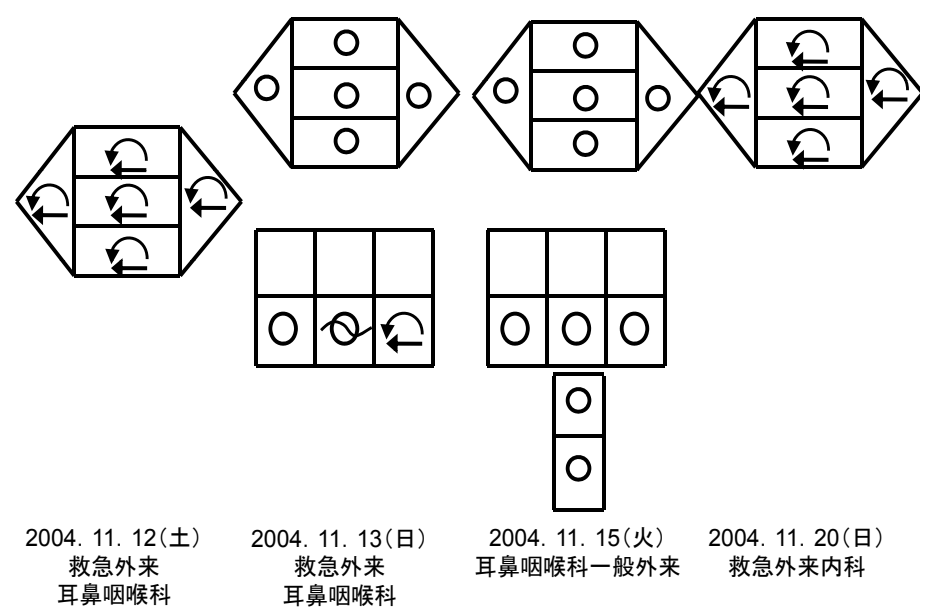

図2 症例 1 眼振所見の変化

する所見があり中枢病変を疑うこととなった。小 脳梗塞・出血例では初診時眼振を認めなかった 4 例中 3 例で, その後眼振が出現した。前述の症例 10は小脳出血にて脳神経外科入院し保存的に治療 され, 症例12)は翌日定方向性水平性眼振が出現, 意識障害もあり, 出血性脳梗塞の診断にて脳神経 外科で緊急手術が施行された。

\section{代表症例}

症例 (1)：58歳男性

主訴：回転性めまい

既往歴 : 糖尿病, 高血圧, 高脂血症

現病歴：2004年11月12日20時頃, 自宅で横にな っていたところ回転性めまいが出現し, 21時頃,

当科救急外来を受診した。

初診時所見 : 意識清明, 注視眼振検查で右向き 水平回旋混合性の $\mathbb{I I}^{\circ}$ 眼振がみられた（図 2 )。そ の他神経学的所見, 小脳症状はなかった。足踏み 検査で左向きに90度の偏倚がみられた。左内耳障 害によるめまいが疑われ救急外来で点滴加療をお こなった。点滴終了後の注視眼振は, $\mathrm{I}{ }^{\circ}$ となっ ており, 翌日も休日のため救急外来での点滴を指 示し帰宅した。翌11月13日当科救急外来を受診 し, 注視眼振はなく, 頭位検査左下頭位で右向き の眼振があり，点滴を施行し帰宅した。2 日後一 般外来を受診した際, めまい感は自覚的に消失 し, 聴力検査も異常なく眼振も消失していた。11
月20日起床時, 再び回転性めまいが出現した。す ぐに症状改善し出勤したが午後になり再び症状増 悪した。嘔気嘔吐も伴い, 17時当院内科救急外来 を受診した。右向きの II ${ }^{\circ}$ 眼振, 右顔面神経麻痺, 瞳孔不同, 左眼外転障害を認め, 当院神経内科に 緊急入院となった。入院後, 頭部 MRI で左延䯣 梗塞（図 3 ）を認め, エダラボン（脳保護薬；フ リーラジカル消去薬）にて加療した。高脂血症,

糖尿病, 高血圧に対しては食事療法を行った。軽 度嚥下障害, 構音障害, 右眼軽度外転障害, 左上 下肢失調, 体幹失調残すが ADL は室内で自立し, 他院でリハビリを続けるため転院となった。

症例(14):74歳, 女性

主訴：左難聴, 回転性めまい

既往歴：高血圧症, 高脂血症, 脳梗塞

現病歴：2008年 9 月 12 日, 左顔面痛, 頭痛を自 覚, その後から左難聴と軽度のめまいを自覚し た。9月17日近医脳神経外科を受診し, 頭部 CT 異常なく, その他脳神経症状ないため内耳性めま いの疑いで 9 月 18 日当科を紹介受診した。

初診時所見：意識清明，右向き水平回旋混眼振 が認められ, 注視眼振検査で右向き水平回旋混合 性の II ${ }^{\circ}$ 眼振, 頭位検查でも右向き水平回旋混合 性眼振がみられた（図 4 )。その他の神経学的所 見, 小脳症状はなかった。純音聴力検査では左感 音難聴 (図 4 ), 語音聴力検査では右 $94 \%(75 \mathrm{~dB})$, 
a.

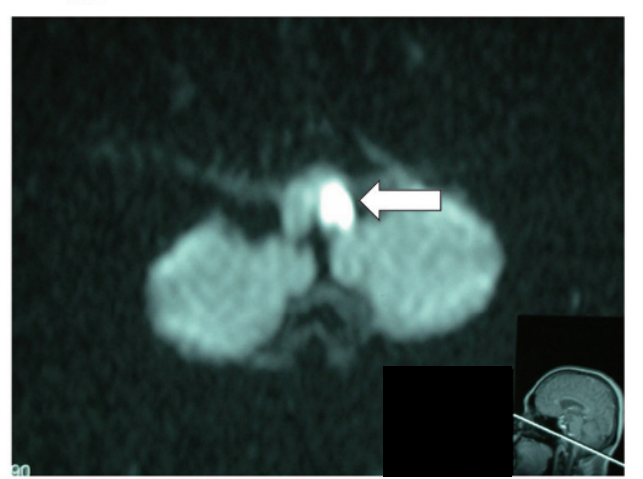

b

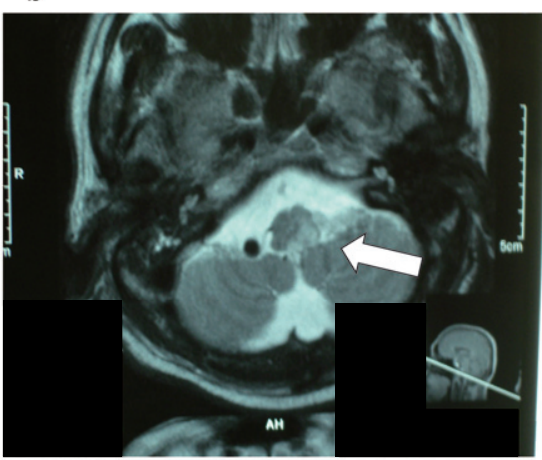

C

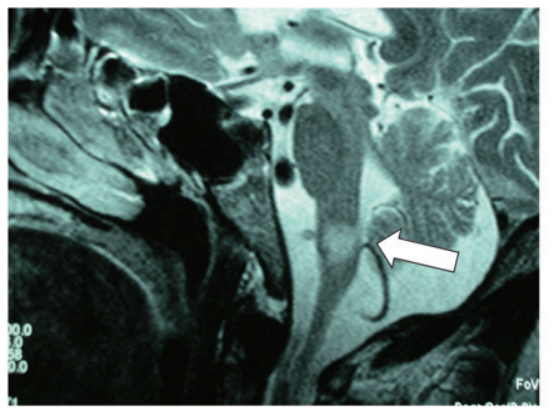

図3 症例 (1) MRI 所見。

$\mathrm{a}$; 拡散強調像, $\mathrm{b}$; T 2 強調画像, 軸位断.

$\mathrm{c}$; T 2 強調画像, 矢状断. 左延髄外側に梗塞像を認める。

左 $54 \%(85 \mathrm{~dB})$ ，耳音響放射検查でも左の反応が 低下していた。前庭誘発筋電位検査では左右とも 反応は良好, 自覚的視性垂直位検査では左側に $12.5^{\circ}$ の偏位があり左内耳障害として矛盾しない 所見であった。めまいを伴う左突発性難聴の診断 で当科緊急入院とし, 糖尿病の既往があるため内 科併科としステロイド漸減点滴治療を開始した。 9 月 19 日, 注視眼振は $\mathrm{I}^{\circ}$ となり 20 日には眼振は 消失したがふらつきと歩行不能状態は続いた。ま た顔面知覚障害, 麻痺が出現し, 緊急 MRI で左 AICA 領域の梗塞が認められた（図 5 )。当院老 年病科に転科しエダラボン（脳保護薬；フリーラ ジカル消去薬）投与が開始された。10月 2 日の診 察時には注視方向性眼振が認められた。

\section{考察 \\ 年齢}

今回の症例は 60 歳代がもっとも多く, ついで 80 歳代, 70歳代, 50歳代の順で, 当然なことではあ
るが高齢者が多かった。しかし30歳代，40歳代の 症例もあり, 椎骨動脈解離が原因と考えられた。 中枢性めまいは比較的若年では稀とされるが椎骨 動脈解離は50歳以下の若年梗塞の原因となるため 注意を要する。その際, 激しい後頸部痛から後頭 部の痛みが生じることが多い。30歳代40歳代の症 例に関しては特に椎骨動脈解離を考慮し後頸部痛 の有無を確認する必要がある3)。

\section{既往歴}

脳梗塞の危険因子については, 診察時特に注意 すべきである。高齢, 高血圧, 糖尿病, 心疾患, 脂質代謝異常, 高へマトクリット值, 喫煙, 肥満, 経口避妊薬の内服などが脳梗塞の危険因子として 知られている。高血圧症は最も危険な因子である が 15 例中 5 例あり, 糖尿病は 5 例, 高脂血症が 3 例あった。一方明らかな既往症のない症例も 5 例 あり，危険因子を有する症例はもちろんである が，既往に危険因子を有さない症例に関しても慎 重な経過観察が必要である。 

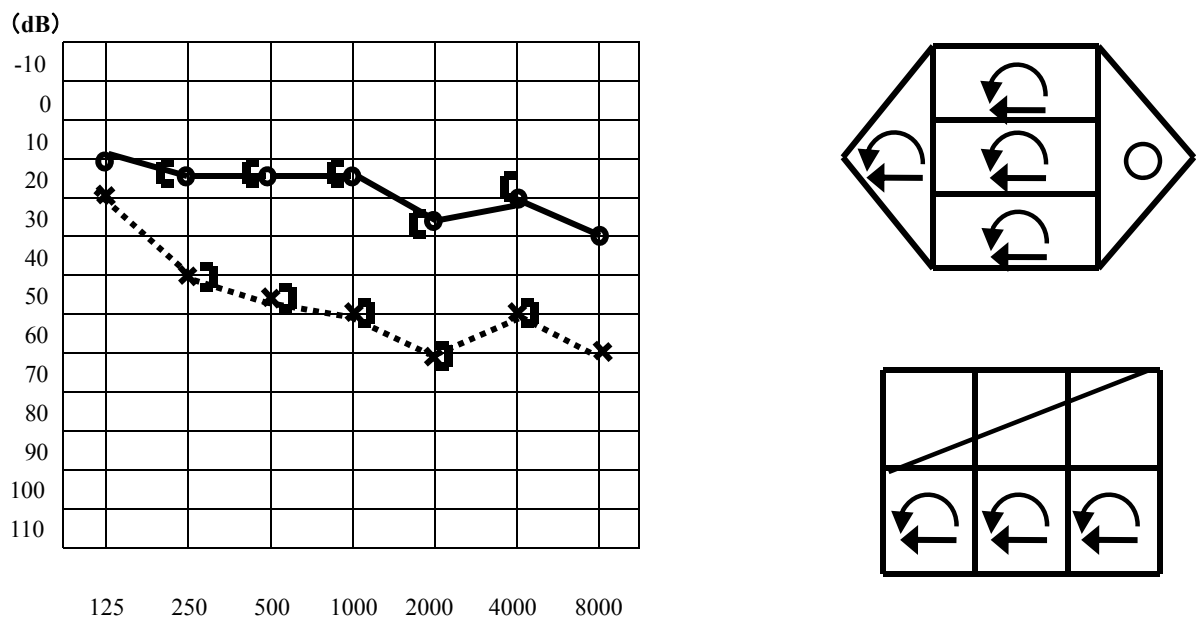

$(\mathrm{Hz})$

図4 症例(14) 初診時純音聴力検査, 眼振所見

\section{めまいの性状}

今回の検討では15例中12例に回転性めまいの訴 えがあった。羽柴ら ${ }^{6)}$ の脳梗塞11例の検討でも, めまいの性状は11例中 8 例, 水野ら ${ }^{7)}$ も19例中 13 例が回転性めまいであったとしている。めまいの 性状から安易に回転性を末梢性, 浮動性を中枢性 とみなすことは非常に危険であり ${ }^{8)}$ ，末梢性，中 枢性の鑑別も困難と考えられた。

初診時眼振所見

\section{1 ) 延髄障害}

脳幹障害の 6 例は初診時全例自発眼振をみとめ た。注視検査では眼振は定方向性で, 注視方向性 眼振や垂直性眼振といった中枢性を示唆する眼振 はみられなかった。延髄梗塞の 3 症例では, 自発 眼振, 注視眼振は健側向きの水平回旋混合性眼振 であった。延髄病変に特徴的とされる回旋性眼振 は今回の検討では認めなかった。Wallenberg 症 候群における自発眼振について, 多くは水平性か 小さな垂直成分を含んだ水平回旋混合性で, 眼位 が中央の時, 緩徐相は患側に向かうことが多いと 述べられている 症早期に水平方向一定性の眼振がみられた 8 例中 6 例は健側向きであったとしており, 今回の症例 と一致した。眼振に関与する延髄の部位は一般に 前庭神経核, 下小脳脚, 下オリーブ核, 舌下神経 前位核などである。Cranmer ${ }^{11)}$ はサルの実験で前
庭神経核・内側核を刺激し同側への水平性眼振を 認め, 同部位を破壊すると反対側に向かう眼振が 出現したと報告している。しかし延髄外側梗塞の 眼振所見の性状に関しては必ずしも一定した傾向 はなく, 水平性, 垂直性あるいは水平回旋混合性,

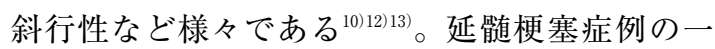
方向性水平性, 水平回旋混合性眼振に関しても患 側に向かうというものと健側に向かうという報告 が混在し, 一致した見解は得られていない。臨床 的な経過に応じて虚血性病変部位の周辺の浮腫な ど可逆的病変が加わり, 前庭神経核周辺の障害部 位が経時的に変化するためと考えられる。また眼 位により眼振方向が変化するので注意深い眼振の 観察が必要である。

延髄内側梗塞では対側の片麻痺, 舌下神経麻痺 の 3 徵からなる Dejerine 症候群が特徵的であ る。症例(3) 3 徵を呈しており Dejerine 症候群 と考えられた。延髄内側梗塞30例の眼振に関する 荒井ら ${ }^{14)}$ の報告では, 上眼瞼向き眼振が 10 例, 下 眼瞼向き眼振が 1 例, Bruns 眼振を含め, 注視方 向性眼振は12例にみられたとしている。定方向性 眼振は水平, 水平回旋性眼振を含め 9 例にみら れ, 眼振の方向は患側向きが 7 例, 健側向きが 2 例であったとしている。

2 ）橋梗塞

橋部脳幹の中でも, 特に背側部は眼球運動にと 
a

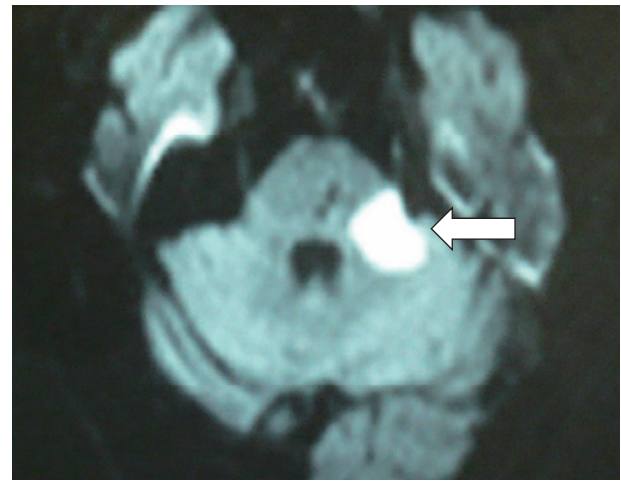

b

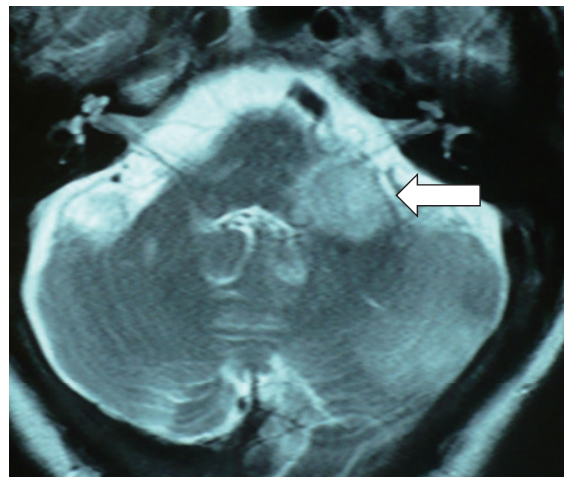

図5 症例(14) MRI 所見 $\mathrm{a}$ : 拡散強調像.

$\mathrm{b}$ ：T 2 強調画像，軸位断. 左 AICA 領域に梗塞を認めた

つて重要な部位である。特に水平眼球運動系に重 要な役割を果たす内側縦束 (medial longitudinal fasciculus, MLF) や脳幹網様体旁正中带 (paramedian pontine reticular formation, PPRF) などが 存在しているため水平眼球運動系に著明な障害を もたらすが, 今回の橋梗塞の 3 例では MLF 症候 群, one-and-a-half 症候群などは認めず, 側方注 視の保持困難などの水平性眼球運動の障害もなか ったが, 一方向性の水平回旋混合性眼振がみられ た。橋部脳幹障害では, 病期により眼球運動の様 相が変化するとされている。早期では障害と反対 側を注視させたときに微細な眼振が認められ, 障 害側注視では眼振は存在せず, 正面視では眼振は 認められないか存在してもきわめて軽度で，その 方向は多くの場合, 障害側と反対を向き, 障害が さらに進むと障害側注視でも眼振が認められるよ うになるとされる ${ }^{15)}$ 。症例(5)では, 初診時左向き 水平回旋混合性眼振がみられ, 翌日には注視方向 性眼振が観察された。MRI 拡散強調像では病変 はほぼ中央であり, 左右への偏位は明らかでなか ったが, 上記の橋梗塞の障害の推移からすると右 側に主病巣があり, 徐々に梗塞部位からの病変の 拡大, 浮腫等による圧迫により障害が進み注視方 向性眼振が観察されるようになったと思われた。

中小脳脚は, AICA で潅流されることが一般的 であり, AICA 症候群の中で論じられることが多 い。今回の症例（症例(4)）は中小脳脚に限局した
梗塞であり橋梗塞に含めた。高松ら ${ }^{16)}$ は中小脳脚 に限局した梗塞 7 例について検討しており, 神経 徵候として難聴は 1 例 $(14 \%)$, 回転性めまいは 4 例（57\%）と報告している。通常の AICA 領域 梗塞の統計に比べ，難聴，めまいの出現割合が低 い。今回の症例では初診時健側向き注視眼振が認 められ, 他の AICA 領域梗塞を主とする症例と同 様に眼振は健側向きであった。しかし蝸牛症状は なかった。

3 ) AICA 領域梗塞

AICA は脳底動脈から分岐し橋外側部, 中小脳 脚, 片葉に加えて内耳を潅流している。AICA 領 域である末梢迷路受容器, 第 8 脳神経, 前庭神経 核，前庭小脳に虚血が生じると末梢性と中枢性の 前庭機能障害が合併する可能性がある。AICA 領 域の梗塞では，一側の難聴，回転性めまいを呈す ることが多く, 内耳性めまいとの鑑別が困難とな ることが多い。AICA 領域に主に梗塞巣がみられ た 3 症例中 2 例に注視眼振がみられ, その他の 1 例では注視眼振はみられなかったが, 頭位検査で 眼振がみられた。いずれの眼振も定方向性であ り, 病巣と反対側に向かう眼振であった。AICA 領域梗塞例の眼振について, Lee (7) $^{17} 12$ 例の検 討で全例, 健側へ向かう水平回旋混合性の自発眼 振がみられたとしている。その他渉猟しえた AICA 領域梗塞に関する過去の報告例 ${ }^{17)}$-30) の初診 時眼振所見をみると, 自発眼振もしくは注視眼振 
の記載があった 13 例中 3 例は注視方向性眼振, 2 例は純回旋性眼振, 1 例は下眼瞼向き眼振のよう な中枢障害を疑う眼振所見であるが，6例では, 健側方向へ向かう水平性もしくは水平回旋混合性 眼振と記載されている。このような症例では一側 の難聴があり，健側へ向かう一方向性の眼振がみ られ，めまいを伴う突発性難聴など内耳性めまい との鑑別が困難であることが想像できる。入院後 2 例は 3 日目， 4 日目に顔面神経麻痺が出現し た。症例14 は初診時注視検査で II ${ }^{\circ}$ 右向き定方向 性水平回旋混合性眼振がみられたが，この眼振は 3 日ほどで消失しその後注視方向性眼振が出現し た。発症当初症状は感音難聴と健側へ向かう眼振 のみであったがその後, 顔面神経麻瘏, 小脳半球 症状が出現した。発症当初, 第 8 脳神経, 前庭神 経核に対する血流が低下し, 梗塞病変の進行によ り前庭小脳に虚血が生じ, 注視方向性眼振が出現 したと思われた。

\section{4) SCA 領域梗塞・出血}

SCA は橋上部，中脳下部の背外側を潅流し小 脳半球および虫部の上約 $2 / 3$ の部分を潅流して いる。桑原ら ${ }^{31)}$ は上小脳動脈領域梗塞 8 症例につ いて検討している。回転性めまい, 眼振を認めた 症例は 8 例中 1 例 $(16 \%)$ で, 比較した AICA 群 で75\%, PICA 群で $86 \%$ と高頻度に回転性めま い, 眼振が認められるのに比べ，低頻度であると 報告している。Kase ら ${ }^{32)}$ は急激に発症する歩行 障害と同側の四肢失調が特徴で, 回転性めまいや 頭痛はまれであり，予後は良好と述べている。 Barth $ら^{5)}$ も構音障害と歩行時不安定さが重要で あると述べている。今回我々の検討では，主に SCA 領域に梗塞・出血を認めたのは 4 例（症例 (7)-(10)であった。初診時 4 例中 1 例に注視検査 で水平性眼振がみられた。小脳出血であった症例 (10は, MRI， CT から SCA 内側枝潅流域の出血と 考えられた。SCA 領域の梗塞では, AICA, PICA 領域の梗塞に比べ，回転性めまい，眼振の頻度は 少ないが下肢に優位な運動失調, 構音障害が比較 的高頻度にみられるとされており，眼振所見を認 めないふらつきの強い症例の場合, SCA 領域梗 塞を念頭におくべきと思われた。

5 ） PICA 領域小脳梗塞・出血

PICA は, 椎骨動脈より分岐し延髄背外側, 小 脳半球, 虫部の尾側を潅流している。延髄外側症
候群を呈さない PICA 領域小脳梗塞を 2 例経験し た。いずれの症例も初診時救急外来での眼振は認 めなかったが，1例はその後注視方向性眼振が出 現し (症例(11)), 出血性梗塞であった症例(12), 翌日から病巣側へ向かう水平性眼振が認められ た。濱田ら ${ }^{33}$ は PICA 領域小脳梗塞 5 例の急性期 について検討しているが，5例中 3 例に注視眼振 を認め， 2 例は患側向き一方向性で，1例は注視 方向性眼振であったと報告している。藤本ら ${ }^{34}$ は, PICA 領域小脳梗塞10例中 4 例に水平性注視 眼振がみられ 3 例は患側向きであったと報告して おり，AICA 領域梗塞と定方向性眼振を呈した症 例の眼振の向きが反対の傾向があった。Igarashi $ら^{35)}$ は小脳虫部の一側の摘出により重度の平衡障 害と病巣側へとむかう自発眼振を認めたとしてお り, 病変の進行により小脳虫部に虚血が生じ, 病 巣側へとむかう自発眼振, 注視方向性眼振が出現 したと考えられた。

内耳性めまい, 中枢性めまいの鑑別

耳鼻咽喉科救急外来のめまい疾患に関する著者 $ら^{1)}$ の検討では $1.4 \%$ ，また伊藤ら ${ }^{2)}$ は $1.9 \%$ と高 率ではないがめまい救急患者の数\%に脳出血・脳 梗塞が含まれている。このような症例は一般外来 でなく，救急外来を受診することが多いのが特徴 的である。救急診療では一般外来に比べ, 問診, 診察, 検査が制限される。今回の検討では, 注視・ 頭位検査で眼振がない例か水平性, 水平回旋混合 性定方向性眼振を呈し，中枢性を強く疑うような 所見はなかった。眼振の方向から中枢性・末梢性 を判断することは困難と考えられた。注視方向性 眼振，頭位検査にて垂直性眼振を認めた症例もあ つたが，いずれも初診時にみられた定方向性眼振 が消失した後，もしくは初診時眼振所見がなく， 入院後の経過観察中であった。また中枢性めまい の診断の重要な因子となるめまい, 眼振以外の神 経症状も初診時明らかでなく，中枢性を示唆する 眼振と同様に遅れて発現する傾向であった。めま い患者の嘔気, 嘔吐, めまい感の強さで神経所見 が十分に把握できないことも原因と考えられた。

急性期めまい患者の診察にあたる耳鼻咽喉科医 にとって，眼振検査は中枢・末梢疾患の鑑別のた め重要な検査である。しかし今回の検討では眼振 の方向によって中枢・末梢疾患の鑑別は困難であ るといわざる得ない結果であった。しかし，眼振 
検査は耳鼻咽喉科医にとって他科に比べ専門性を 発揮できる重要な検査であることに変わりはな い。注視眼振, 頭位眼振ともに経時的変化が激し く, 頻回に観察することにより中枢性を示唆する 眼振の出現を見逃さぬよう努めることが脳血管障 害例の診断を早めるために重要であると考えられ た。また眼振の方向だけでなく，眼振リズムの不 規則性, 注視でみられた眼振が非注視下で消失す る，眼位による変化など眼振の性質に関しても注 意深く観察する必要があると考えられた。また, 今回の検討では，診療録に詳細な記載はなかった が，急性期小脳梗塞症例で激しいめまいのために 患側下側臥位から動けなくなる症例が16例中 4 例 にみられたと藤本ら ${ }^{34)}$ は報告しており，眼振以外 にも患者の頭位に関しても注意が必要と考えられ た。このように神経耳科的慎重な観察を行い, 中 枢障害が疑われる症例に関しては可能な限り速や かに MRI 検査を計画することが重要である。

\section{まとめ}

(1)内耳性めまいが疑われ当科を受診後中枢性め まいが判明した15例について検討した。

(2)初診時眼振所見は定方向性水平性もしくは水 平回旋混合性の注視, 自発, 頭位眼振が多かった。

(3)脳幹梗塞例に比べ小脳梗塞・出血例では初診 時注視, 自発, 頭位眼振所見のない症例が多かっ た。

(4)入院後眼振所見は経時的に変化し，めまい, 眼振以外の神経学的所見が遅れて発症する傾向が みられた。

(5)初診時頭部 CT は脳幹梗塞には無力である が，小脳出血の確認に有効な場合があり，また， 速やかに MRIによる検索を行うことが望ましい と考えられた。

\section{文献}

1 ）小川恭生, 萩原 晃, 北島尚治, 他 : 救急外 来を受診しためまい症例の臨床統計。耳鼻臨 床 $100: 17-24,2007$

2 ）伊藤彰紀：めまい急患の取り扱いについて. 高橋正紘編. めまい診療のコツと落とし穴. 12 頁, 中山書店，東京， 2005

3）久米淳子, 小川恭生, 萩原 晃, 他：めまい で発症した椎骨動脈解離の 4 例。耳鼻臨床 $99: 623-633,2006$

4 ）小川恭生：診断困難な症例に学ぶ 鑑別困難
であっためまいの 2 症例．耳鼻と臨 50 ： 188-194, 2004

5 ) Barth A,Bogousslavsky J, Regli F: The clinical and topographic spectrum of cerebellar infarcts. A clinical-magnetic resonance imaging correlation study. Ann Neurol 33:451456, 1993

6 ）羽柴基之, 渡邊暢浩，服部輝昭：めまいで耳 鼻咽喉科を受診した脳梗塞11例．Equilibrium Res 58: 262-269, 1999

7 ）水野正浩，伊藤彰紀，吉岡克己, 他：めまい を主訴とした脳血管障害例。Equilibrium Res 63: 117-124, 2004

8 ）城倉 健：脳卒中とめまい。日医師会誌 $134: 1485-1490,2005$

9 ) Leigh RJ, Zee DS: Ocular motor syndromes caused by lesion in the medulla. Leigh RJ, Zee DS. The neurology of eye movements. pp 482-486, Oxford University Press, New York, 1999

10）水見徹夫，形浦昭克：ワレンベルグ症候群に おける延髄病変部位と自発眼振との関連. Equilibrium Res 52: 175-180, 1993

11) Cranmer DR: Nystagmus related to lesions of the central vestibular apparatus and the cerebellum. Ann Otol Rhinol laryngol 60: 186196, 1951

12）新井基洋, 徳増厚二, 藤野明人, 他 : Wallenberg 症候群の眼振について. Equilibrium Res 52: 544-551, 1993

13）木村元俊，梅田悦生，児玉 章，他：Wallenberg 症候群の眼振所見の変化について。耳 鼻咽喉 58：485-492，1986

14）荒井元美，志智大介：錐体路障害と舌下神経 麻痺を欠き，中枢前庭機能障害がみられた延 䯣内側梗塞の 3 例。臨神 経 39:10591063, 1999

15）小松崎 篤：脳幹障害における眼振と異常眼 球運動．小松崎 篤，篠田義一，丸尾敏夫 編. 眼球運動の神経学. 258-278頁, 医学書 院，東京， 1985

16）高松和弘, 大田泰正, 佐藤昇樹, 他：中小脳 脚梗塞の検討. 脳卒中 $19: 138-143,1997$

17) Lee H, Sohn SI, Jung DK, et al.: Sudden 
deafness and anterior inferior cerebellar artery infarction. Stroke 33: 2807-2812, 2002

18）那須 隆, 中村 正, 横田雅司, 他 : 急性感 音難聴で発症した脳幹梗塞の 1 例. Equilibrium Res 57: 289-296, 1998

19) 中山明峰, 稲福 繁, 堀 瑞代, 他: 前下小 脳動脈症候群と内耳動脈症候群（仮称）耳 鼻臨床 $82: 1693-1700,1989$

20）中山明峰, 稲福 繁, 滝本 勲, 他 : 顔面麻 痺が後発した前下小脳動脈症候群. 耳鼻臨床 $86: 315-320,1993$

21）大石直樹, 武井 聡 : 蝸牛前庭症状を初発と した脳梗塞症例.耳鼻展望 48 :292297, 2005

22）小川恭生, 藤田博之, 萩原 晃, 他 : 突発難 聴, めまいで発症した前下小脳動脈梗塞の 1 症例. 耳鼻展望 $43: 49-53,2000$

23）藏内隆秀, 矢部多加夫, 吉本 裕, 他 : 急性 感音難聴, 平衡障害で発症した前下小脳動脈 領域の脳幹梗塞症例. 耳鼻・頭頸部外科

67 : 1041-1046, 1995

24）大平泰行, 前田秀彦, 木村元俊, 他 : 突発性 高度難聴とめまいにて発症した前下小脳動脈 血栓症の 1 例. 耳展 $30: 511-518,1987$

25）姫野千恵美, 古川昌幸, 柿本晋吾, 他 : 回転 性めまい, 急性高度難聴で発症した前下小脳 動脈症候群の 1 例。耳展 $45: 49-53$, 2002

26）菊田 周, 武田英彦, 熊川孝三, 他：めまい, 難聴で発症した小脳・脳幹梗塞例. 耳鼻臨床 100：255-259, 2007

27）松本 康, 相原隆一, 河村裕二, 他：小脳梗 塞症例にみられた突発難聴. 愛媛医 10 ：
618-622, 1991

28）岩崎 聡, 森 泰雄, 大蝶修司 : 急性感音難 聴で発症した前下小脳動脈症候群。耳鼻臨床 $85:$ 169-173, 1992

29) Son EJ,Bang JH, Kang JG: Anterior inferior cerebellar artery infarction presenting with sudden hearing loss and vertigo. Laryngoscope 117: 556-558, 2007

30) Kido T, Sekitani T, Okinaka Y, et al.: A case of cerebellar infarction occurred with the 8 th cranial nerve symptoms. Auris Nasus Larynx 21: 111-117, 1994

31）桑原 聡, 平山恵造, 小島重幸, 他 : 上小脳 動脈領域梗塞の臨床的特徵. 脳卒中 14 : 159-165, 1992

32) Kase CS, White JL, Joslyn JN, et al.: cerebellar infarction in the superior cerebellar artery distribution. Neurology 35: 705-711, 1985

33）濱田敬永, 斉藤雄一郎, 遠藤壮平, 他 : めま いを主訴とした後下小脳動脈領域梗塞一MRI で確認し得た新鮮梗塞 5 症例の検討一. Equilibrium Res 53: 381-392, 1994

34）藤本正也, 大橋寿彦, 清水秀昭, 他 : 急性期 小脳梗塞の追う MRI 画像と臨神経的所見に 関する検討. 臨神経 37 : 580-586, 1997

35) Igarashi M, Miyata H, Alford BR, et al.: Experimental cerebellar uvulonodular lesions in the squirrel monkey. Adv Otorhinolaryngol 19: 220-231, 1973

36) Duncan GW, Parker SW, Fisher CM: Acute cerebellar infarction in the PICA territory. Arch Neurol 32: 364-368, 1975 